Bulgarian Academy of Sciences, Space Research and Technology Institute.

Aerospace Research in Bulgaria, 29, 2017, Sofia

\title{
INNOVATIONS IN THE AREA OF UNMANNED AERIAL VEHICLES
}

\author{
Petar Getsov ${ }^{1,2}$, Wang Bo ${ }^{1}$, Svetoslav Zabunov ${ }^{2}$, Garo Mardirossian ${ }^{2}$ \\ ${ }^{1}$ Ningbo University of Technology - China \\ ${ }^{2}$ Space Research and Technology Institute - Bulgarian Academy of Sciences \\ e-mail: bo305@hotmail.com; office@space.bas.bg
}

\begin{abstract}
The current paper discloses some innovations in the field of unmanned aerial vehicles. The latter were developed recently at Space Research and Technology Institute at the Bulgarian Academy of Sciences. This article shows the advantages of the arrangement, and the technical and operating characteristics of the following inventions:

- Multirotor Helicopter

- Tandem Helicopter

- Vertical Take-off and Landing Aircraft

- $\quad$ Three Phase Brushless Direct Current Motor Control System

- Unmanned Aerial Vehicles Antenna System

- Wireless Universal Serial Bus Realized through Telemetry Radio Link for Unmanned Aerial Vehicles

All of the presented innovations are subject to patent protection, while most of them have been honoured with the highest awards at international foreign forums for innovations.
\end{abstract}

\section{Introduction}

Due to its simplicity, reliability, comparatively easy technical servicing and maintenance, as well as the ability to take-off and land from runways with minimal dimensions, the unmanned aerial vehicles (UAVs), also known as drones, are entering more and more different areas of human activities. This development motivates active work for optimization of their major technical and operating parameters - weight, energy consumption, flight duration, etc.

The current article is devoted to some innovations in the field of UAVs that were introduced in the last few years at Space Research and Technology Institute the Bulgarian Academy of Sciences. All of the presented innovations are subject to patent protection, while most of them have been honoured with the highest awards at international foreign forums for innovations. 


\section{Multirotor Helicopter}

The multirotor helicopter named "Bulgarian Knight" [7] is presented on Fig. 1 . It consists of twelve rotors $1^{\mathrm{I}}, 1^{\mathrm{II}}, \ldots, 1^{\mathrm{XII}}$, mounted below the helicopter airframe plane 2 using an optimal configuration of the rotors. The latter establishes maximum coverage without overlap. The airframe configuration represents a pair of parallel beams $2^{\mathrm{I}}\left(2^{\mathrm{I}-1}\right.$ and $\left.2^{\mathrm{I}-2}\right)$, to which another pair of parallel beams $2^{\mathrm{II}}\left(2^{\mathrm{II}-1}\right.$ and $2^{\mathrm{II}-2}$ ) is attached. The two pairs of beams are orthogonal to each other and lie in the same plane.

This configuration is applicable to unmanned and manned aerial vehicles, propelled by electrical motors. Such aircraft may be used in various activities such as scientific research operational tasks with civilian or military pattern. By means of the aerodynamic forces, created by the rotors, flight of the helicopter is maintained and its motion in the air in vertical and horizontal direction is controlled. The accelerated airflow, created by the rotors, and directed downwards, does not interfere with the airframe, positioned above the rotors, and hence avoidance of aerodynamic drag in the downward direction is achieved. The latter drag is undesirable.

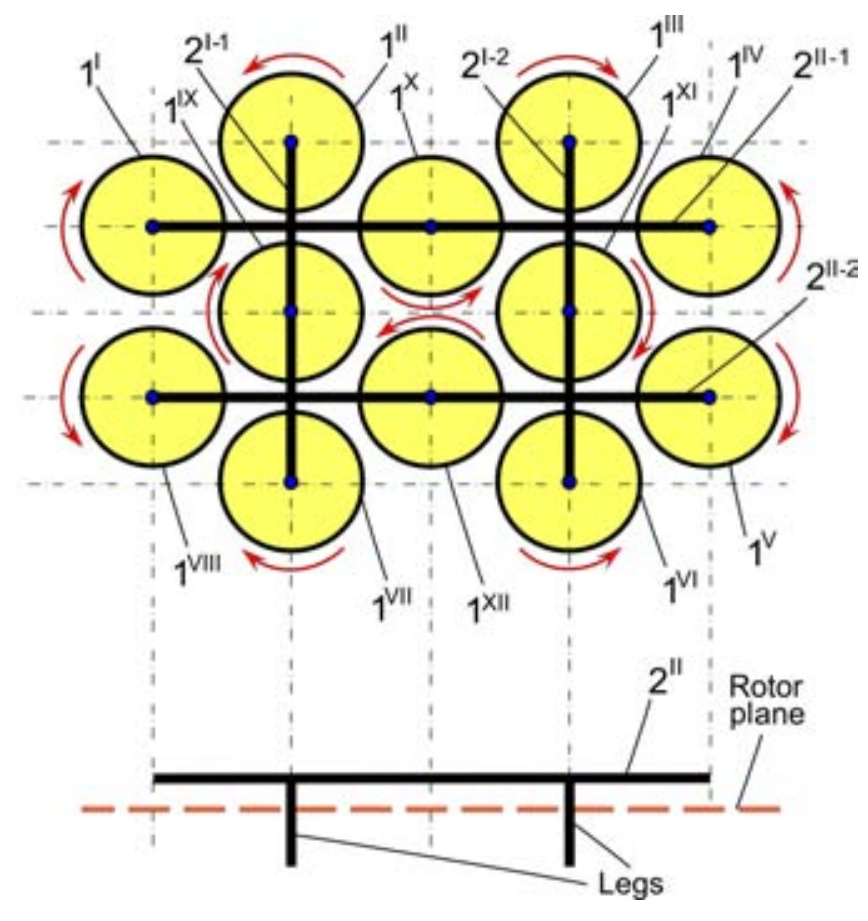

Fig. 1. Scheme of the twelve rotor helicopter "Bulgarian Knight" 
On the other hand, the optimal rotor configuration (the position of rotors in respect to each other) and airframe topology guarantee minimal weight of the flying machine. By doing so, flight duration, range and payload capabilities are maximized.

\section{Tandem Helicopter}

The tandem helicopter [8] is denoted on Fig. 2. It consists of two horizontal rotors $1^{\mathrm{I}}$ and $1^{\mathrm{II}}$, located under the airframe plane 2 . The airframe configuration represents a horizontal beam $2^{\mathrm{I}}$, at the two ends of which two vertical consoles are mounted $2^{\mathrm{II}}$ and $2^{\mathrm{III}}$. At the top ends of both consoles two pairs of vertical rotors $3^{\mathrm{I}}$, $3^{\mathrm{II}}, 3^{\mathrm{III}}$ and $3^{\mathrm{IV}}$ are installed.

The application of this innovation is in unmanned and manned flying machines, with electrical motors that are used for aerial photography, remote sensing and other activities in the field of defence, fight against organized crime and terrorism.

By means of aerodynamic force, created by the rotors, sustained flight is achieved of the tandem helicopter and its motion in the air in vertical direction. Using the vertical rotors attitude control of the airframe is attained and further horizontal motion is achieved. The accelerated airflow created by the main horizontal rotors and directed downwards does not flow against the airframe. This is due to the airframe being positioned above the horizontal main rotors and in this way undesired aerodynamic drag in downward direction is avoided. Hence, the flight time, range, and the weight of the payload are maximized.

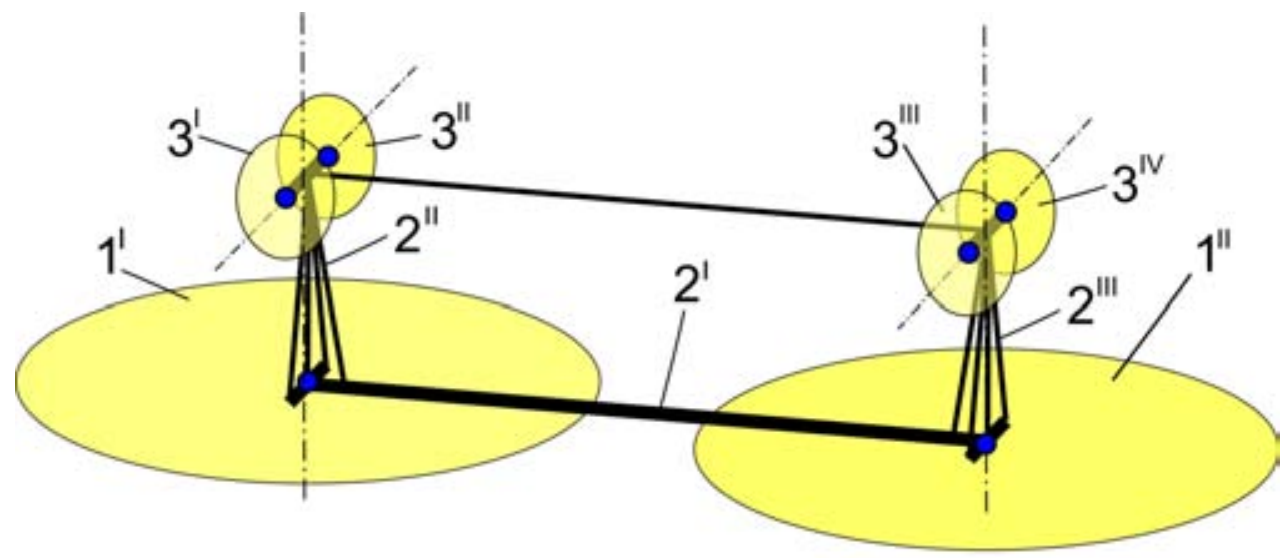

Fig. 2. Scheme of the tandem helicopter 


\section{Vertical Takeoff and Landing Aircraft}

The innovation refers mostly to unmanned aerial vehicles [5]. It consists of a propeller driven fixed wing airplane with vertical take-off and landing capabilities.

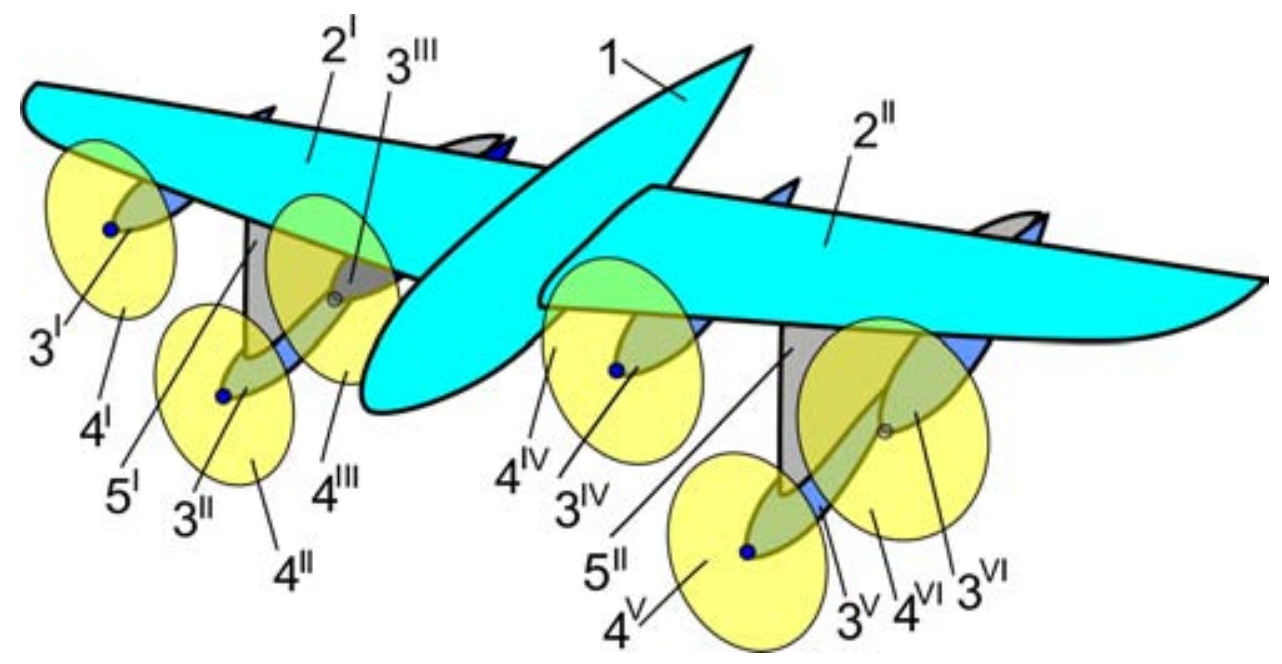

Fig. 3. General view of the VTOL aircraft configuration

The application of this invention is in remote sensing activities, people search and rescue operations, activities relevant to ecology, disaster and industrial accidents and catastrophes, intelligence and reconnaissance, etc. In principle the invention may be used with manned aircraft.

The discussed airplane has two modes of flight: helicopter and airplane mode. The take-off and landing procedures are carried out in helicopter mode. In this mode the aircraft lands on its tail using the consoles supporting motor nacelles as landing legs. The normal flight is performed in airplane mode. Transition from helicopter flight mode to airplane flight mode and vice versa, is achieved through reorientation of the airframe. Flight direction in airplane mode is defined by the fuselage streamlined form similarly with any other fixed wing airplane.

According to Fig. 3 the aircraft consists of a fuselage 1, fixed wing 2 attached to the latter (right half wing $2^{\mathrm{I}}$ and left half wing $2^{\mathrm{II}}$ ). The wing carries six motor nacelles 3 with motors inside, four of which are mounted directly to the main wing and two - using consoles 5 (see Fig. 3). All motors are turning fixed pitch propellers 4 . 


\section{Three Phase Brushless Direct Current Motor Control System Used in Drones}

The following invention [1,2] is a system for control of three phase brushless direct current motors used in drones. The invention improves the efficiency of motor control and consequently the efficiency of flight in comparison with the existing systems. It is applicable to drones (helicopters and airplanes) that are propelled using electric energy stored in batteries.

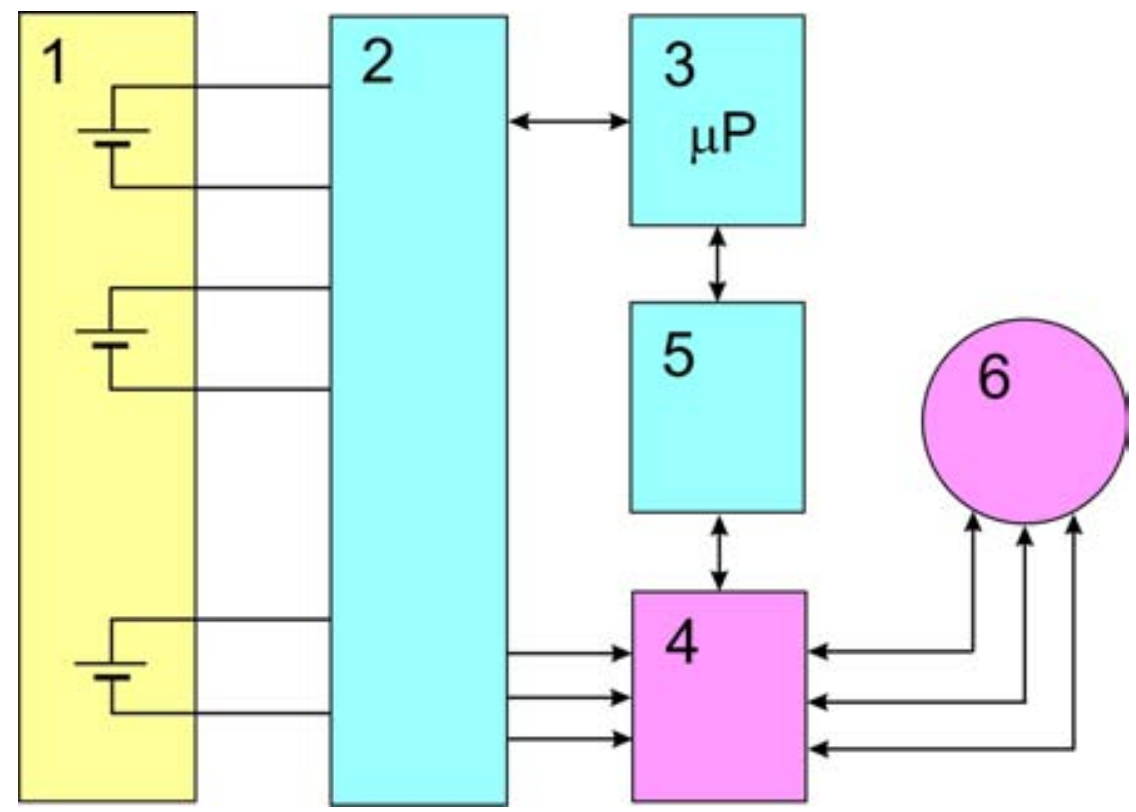

Fig. 4. Block schematic of the three phase brushless motor control system

Through commutation of the battery cells, according to the current mode of flight, efficiency is improved and flight time is enhanced. The system is shown on Fig. 4 . It consists of battery block 1 with battery cells $1^{\mathrm{I}}, 1^{\mathrm{II}} \ldots 1^{\mathrm{n}}$. The battery cells terminals are connected to commutator block 2. The latter is connected to electric motor control block 4 and commutator control block 3. Commutator control block is connected to command block 5. The latter is in connection with the electric motor control block. Finally, the electric motor control block has three connections to the three phase coils of the electric motor 6.

The application of this invention, besides in electrically propeller UAVs, may be in home appliances, electric cars, boats and ships, etc. that use electric energy from an electric battery as power supply. 


\section{Unmanned Aerial Vehicles Antenna System}

The invention $[3,4]$ realizes two-way radio link between unmanned aerial vehicle and a ground station. The application is in control of and information exchange with an UAV. The radio link uses circular polarization of the electromagnetic field. The antenna directivity diagram is adjusted electronically and dynamically through a phased antenna array in congruence with the momentary orientation of the drone.
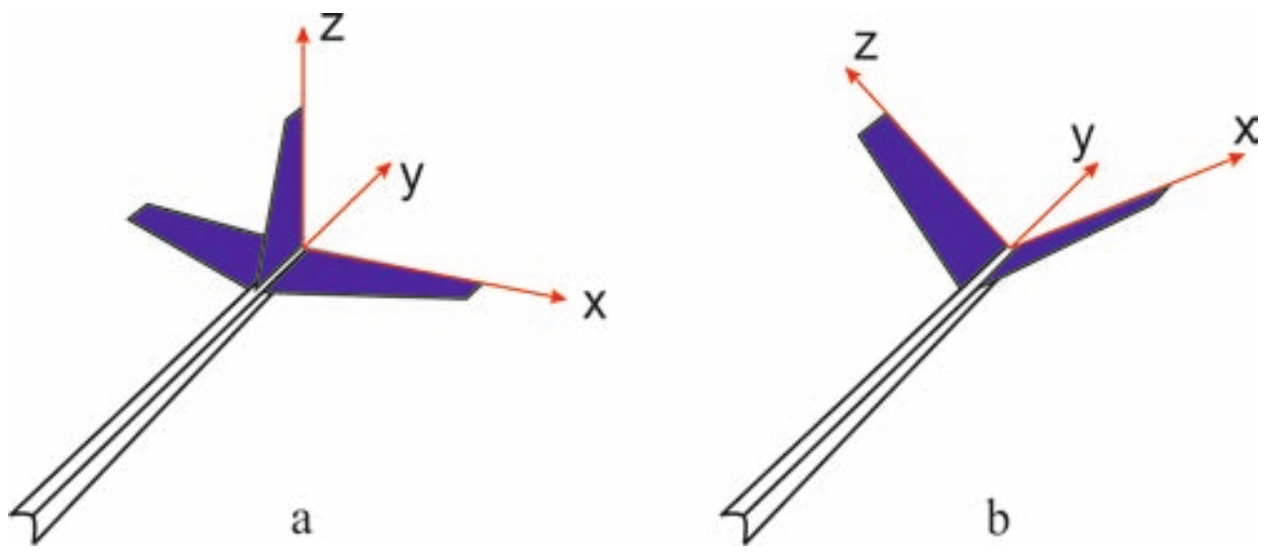

Fig. 5. Antenna elements position in the aircraft empennage:

a) Classic empennage, b) V-tail empennage

The antenna system uses the empennage of an unmanned aircraft to dispose the three mutually orthogonal antenna elements $x, y$ and $z$ (Fig. 5).

The block diagram of the invention is shown on Fig. 6. The system consists of three mutually orthogonal antenna elements $1^{\mathrm{x}}, 1^{\mathrm{y}}$ and $1^{\mathrm{z}}$ of the airborne antenna array. The latter are connected to the three bilateral terminals of the commutation block 2 (Fig. 6). The three outputs of the commutation block are connected to the three inputs of the preamplifier 3. Preamplifier's output connections go to the three inputs of the receiver phasing and impedance matching block $4^{\prime}$, output of which is connected to the input of receiver 5 . The fourth input of $4^{\prime}$ is connected to one of the outputs of autopilot 7 . To a triad of inputs of the commutation block 2 the three outputs of the transmitter phasing and impedance matching block 4" are connected. The output of the transmitter 6 goes to the input of block $4 "$. The second output of autopilot 7 is connected to the second input of block 4". The fourth input of commutation block 2 receives signals from the output of command block 8, which is in bilateral connection with the receiver 5 and the transmitter 6 . 


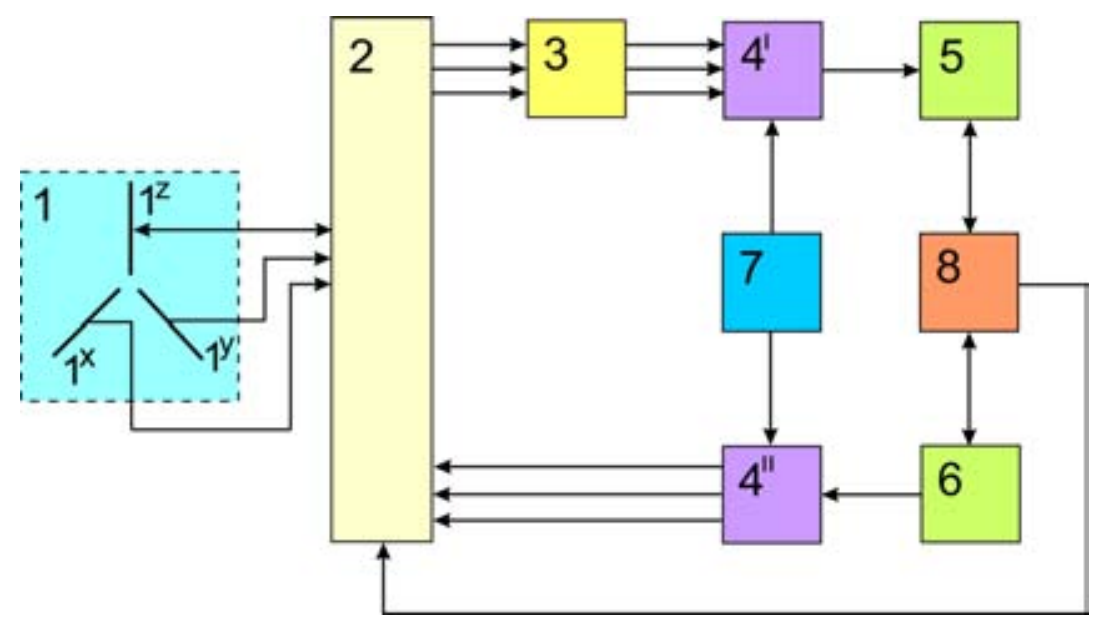

Fig. 6. Block-diagram of the antenna system

\section{Wireless Universal Serial Bus Realized through Telemetry Radio Link For Unmanned Aerial Vehicles}

This innovation refers to a wireless universal serial bus (USB), realized using wireless radio link through off-the-shelf telemetry modules for UAVs [6]. The application is with USB-devices onboard of UAVs that, using the invention, may have USB-wireless connection with a ground-based computer. Examples of such devices are web cameras, web microphones, USB-cameras, etc.

Drawbacks of the existing wireless USB technology are related to the used modulations and frequencies. The described invention aims at creating a wireless USB connection that will lack the so described disadvantages of the existing similar devices.
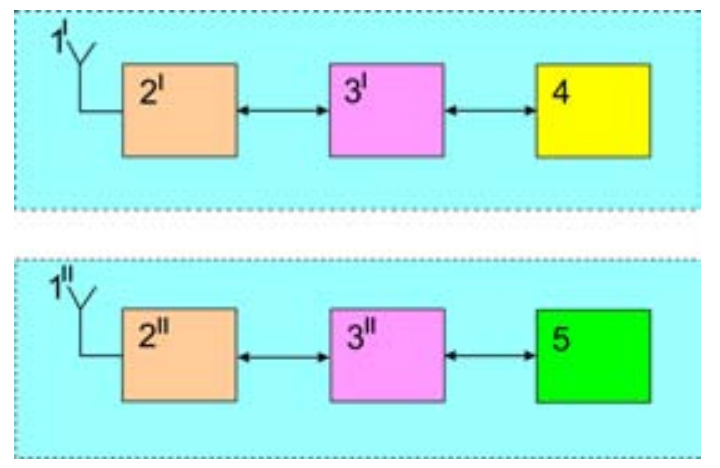

Fig. 7. Block diagram of wireless USB for use over the telemetry radio link of UAVs 
The wireless-USB is presented on Fig. 7. It consists of airborne station and a ground station. The two stations are built out of airborne antenna $1^{\mathrm{I}}$ and ground based antenna $1^{\mathrm{II}}$ respectively. These are connected to airborne module for telemetry $2^{\mathrm{I}}$ and ground based telemetry module $2^{\mathrm{II}}$ respectively. The latter two are in respective bilateral connection with airborne USB interface module $3^{\mathrm{I}}$ and ground based USB interface module $3^{\mathrm{II}}$, which on their part are in bilateral connection with airborne USB device 4 and ground based computer 5 respectively.

The application of this innovation is in electrically propelled unmanned and manned flying machines that are used for aerial photography, remote sensing and other activities in the field of defense, fight against organized crime and terrorism.

Development and testing of some prototypes will be provided in Ningbo University - China.

\section{References}

1. Zabunov, S., P. Getsov, and G. Mardirossian. Control System for Three Phase Brushless Direct Current Motor. Utility model № 2723/04.06.2014. Patent Office of Republic of Bulgaria.

2. Zabunov, S., P. Getsov, and G. Mardirossian. Control System for Three Phase Brushless Direct Current Motor. Patent application reg. № 111705/20.02.2014. Patent Office of Republic of Bulgaria.

3. Zabunov, S., P. Getsov, G. Mardirossian, and G. Sotirov. Unmanned Aerial Vehicles Antenna System. Utility model № 2737/17.03.2014. Patent Office of Republic of Bulgaria.

4. Zabunov, S., P. Getsov, G. Mardirossian, and G. Sotirov. Unmanned Aerial Vehicles Antenna System. Patent application reg. № 111720/12.03.2014. Patent Office of Republic of Bulgaria.

5. Zabunov, S., P. Getsov, and G. Mardirossian. Vertical Take-off and Landing Aircraft. Utility model № 2765/12.05.2014, Patent Office of Republic of Bulgaria.

6. Zabunov, S., P. Getsov, G. Mardirossian, and G. Sotirov. Wireless Universal Serial Bus Realized through Telemetry Radio Link for Unmanned Aerial Vehicles. Utility model № 2804/10.07.2014, Patent Office of Republic of Bulgaria.

7. Zabunov, S., G. Mardirossian. Multirotor Helicopter. Patent application reg. № 112131/02.11.2015, Patent Office of Republic of Bulgaria.

8. Mardirossian, G., P. Getsov, and S. Zabunov. Tandem Helicopter. Patent application reg. № 112529/15.06.2017, Patent Office of Republic of Bulgaria.

9. Ching, T.W. Soft-switching Converters for Electric Vehicle Propulsion. Journal of Asian Electric Vehicles, 2007, 5, 2.

10. http://www.usb.org/developers/docs/usb_31_031114.zip

11. IEEE GET ProgramTM, http://standards.ieee.org/about/get/ (accessed 10 January 2018)

12. Robertson, P. and S. Kaiser, The effects of Doppler spreads in OFDM(A) mobile radio systems, Vehicular Technology Conference, 1999. VTC 1999 - Fall. IEEE VTS. 


\title{
ИНОВАЦИИ В ОБЛАСТТА НА БЕЗПИЛОТНИ ЛЕТАТЕЛНИ АПАРАТИ
}

\author{
П. Гецов, В. Бо, С. Забунов, Г. Мардиросян
}

\section{Резюме}

В статията са представени някои иновации в областта на безпилотни летателни апарати, разработени през последните години в Института за космически изследвания и технологии при Българска академия на науките (ИКИТ-БАН). Показани са накратко идеята, конструкцията и техникоексплоатационните характеристики на следните иновациионни разработки:

- Мултироторен хеликоптер,

- Тандем хеликоптер,

- Самолет с вертикално излитане и кацане,

- Система за управление на трифазен безколекторен електродвигател,

- Антенна система за безпилотен летателен апарат,

- Безжична универсална серийна шина за телеметрия на безпилотни летателни апарати.

Всички представени иновации са обект на патентна защита и са отличени с високи награди на наши и международни иновационни форуми. 